\begin{tabular}{|r|c|c||}
\hline Received: March 2018 & Accepted: March 2018 & Published: April 2018 \\
\hline \hline Article DOI: http://dx.doi.org/10.24903/sj.v3i1.200 \\
\hline
\end{tabular}

\title{
Stakeholder Perspective toward English Language Teaching in Pesantren
}

\author{
Muhammad Zuhri Fakhruddin \\ Universitas Muhammadiyah Sidoarjo \\ mz.fakhruddin93@gmail.com \\ Fika Megawati \\ Universitas Muhammadiyah Sidoarjo \\ fikamegawati@umsida.ac.id
}

\begin{abstract}
In the teaching and learning activity, condusivity and effectivity are determined by various factors, such teacher and students' behavior, teaching instrument, methodology and material structure. Each stakeholder may have different perspective upon these various aspects and perhaps- will significantly influence their behavior toward the activity of teaching and learning. In a premise that a positive behavior and constructive collaboration is built on a linier perspective among stakeholders, this small scale research intends to investigate stakeholders' perspective upon English Language Teaching in Pesantren Bilingual Al Amanah, Junwangi, Krian. Through a direct structured interview with stakeholders (teacher, head of language enforcement, and some representative students), researcher collects the data to be analyzed, interpreted and presented in an analytical descriptive report. The finding will be significant toward the foundation of stakeholders' harmonization, enhancement of teaching method, development of English Language Teaching program in Pesantren as well as a milestone of further research and innovation.
\end{abstract}

Keywords: Stakeholder, Perspective, English Language Teaching, Pesantren

\section{INTRODUCTION}

During English Language Teaching (ELT) activities in Pesantren, many stakeholders are involved in order to create conducive situation which is measured and set up to reach maximum output of the educational process. Among these stakeholders, teacher and students are the main actors to determine, although another stakeholder may be also taking part and become influential. 
Teacher and students have their own perspectives toward the running process of learning, environment and instruments. Students must have personal motivation which determines their perspective as well as learning behavior. Moreover, their perceptions of a learning environment as well as their desired way of learning direct their study behavior, which eventually determines the effectiveness of the environment (Entwistle \& Tait, 1990; Vermetten, Vermunt, \& Lodewijks, 2002) On the other side, teacher as an active subject, may also has perspective which may vary and different to the students. A congruency of perspective from both side -teacher and students- has empirically and scientifically proofed a significant contribution to an optimal learning outcome (Könings, 2007). Based on this theory, the existing discrepancy and even the absence of congruency must potentially drive to un-optimal learning outcome.

In some traditional Pesantren, as observed and exposed by Hidayat (2007) ELT has been taught to the students without enough educational and teaching instrument such syllabus and language laboratory. English teachers also have not convinced language teaching qualification, since they only have Senior High School degree and Language Course Certificate. English Language Teaching in Pesantren is unique due to its potential conflict of culture, since English is notably exporting western culture which perhaps has such contradictive value to Islamic culture. Despite, recently, these conflicts have been successfully managed and driven in to harmonization (Fahruddin, 2015). Furthermore, Risdianto (2016) run his investigation upon method of ELT in Pesantren as he discovered that teacher-centered is the most common method to use by the teacher. In the class, students are learning under army method scheme which provides reward and punishment to organize the class. Nevertheless, students are supported by the environment outside the class and internal regulation which allow the teachers or seniors to give punishment for those who doesn't use official language (Arabic or English). Pesantren has usually developed its own program to support ELT, for instance Muhawaroh - literally means conversation-which deploys daily conversation method (DCM). An investigation which been run by Mukhlas \& Fadhilah, (2016) revealed positive response from the majority of students toward the application of DCM outside the classroom.

Based on previous literature review, so far, studies and investigations regarding to ELT in Pesantren have only concerned to the cultural clash, teaching method, application, programs, and student (one side) perception. The study of perspective congruency between students and teacher, or another stakeholder such head of language enforcement department, 
headmaster and school committee, is not found yet. Therefore, through this small-scale investigation, researcher is honored to step forward to explore the topic of perspective congruency toward English Language Teaching in Pesantren, and present it to the readers and fellow researchers in a scientific report.

\section{METHODOLOGY}

Research methodology is defined as compilation of regulations, procedures, activities and chronological structure which been used by the researcher to run his/her research. It is also may be described as theoretical analysis and approach which is systematically used to process the data in order to identify the problem and later find out the answer the problem scientifically. The design of this small-scale research is quantitative descriptive. A quantitative research is simply described as a study which address question how many and how much. It is based on the measurement of quantity or amount (Kothari, 2004). Meanwhile, a descriptive technique is used to analyze the data which been gathered and interpret it.

The research took place at Pesantren Moderen Al Amanah, Junwangi, Krian which applied integrated model of education between internal curriculum and national curriculum under Ministry of Religious Affair. As a modern Pesantren, the institution has given proper attention on language enforcement to the students by combining classroom activity and outclass activity in the dormitory. There are two language which been recognized as official language in Pesantren, Arabic and English, and therefore the institution had also promoted its identity as bilingual Pesantren, beside other religious attribute.

During the data collection, two methods are used toward different stakeholder. A Questionnaire for student and interview is used for the teachers and head of Language Enforcement Department. 47 students which 25 of them are female and the 22 are male involved answering the questionnaire. The students are all from $\mathrm{X}$ grade of Senior High School and all of them are from Science track. These 47 respondents are chosen due to the availability of time and in accordance with Pesantren regulation which allows only $\mathrm{X}$ grade students to become research object. All of these students are staying in the dormitory with such firm language regulation under language enforcement department. The head of the department is senior student who is still studying at XI grade of Senior High School. Teachers, as one of the stakeholder, are two English teachers who formally teach the students along the academic year. 
Despite two difference method of data collection among stakeholders, the content of each has been designed to reveal and discover similar essential information related to the research topic. There are mainly six variables to measure in the questionnaire; [1] Perspective toward urgency of ELT; [2] Learning Motivation; [3] Application of ELT in Pesantren; [4] ELT method in Pesantren; [5] Teaching and Learning Instrument of ELT in Pesantren and [6] Significance of Supporting Environment toward ELT in Pesantren. Meanwhile, same variables are used in structured questions list for interview with teachers and head of language enforcement department.

Students, teacher and head of language enforcement department are considered as ruling stakeholder who significantly involve in English Language Teaching in Pesantren. Head of language department -specifically- rules the internal regulation which includes reward and punishment to those who are not practicing official language. He is also responsible for the language development program outside the class, for instance Muhawaroh (conversation) and Muhadloroh (public speaking training), therefore he may be considered as representative stakeholder from what we called as the supporting environment. Meanwhile, teachers play their significant rule in the classroom activity. The researcher had actually planned to interview the headmaster and his vice of student affairs, but it was not possible to do so due to tight schedule of these two leaderships.

\section{FINDINGS AND DISCUSSION}

In this section, researcher will present general finding before providing his/her interpretation toward the trend and pattern which been found based on its numerical data. After collecting the raw data from both questionnaire and structured interview, researcher has managed the whole result and compiled in a summary as mentioned below. Each point will numerically describe student perspectives which been measured through the questionnaire.

\section{- Perspective toward urgency of ELT}

In this variable, among all respondents from male and girl students, their choices which considerably represent their perspectives are only driven into 'very important' and 'important. The other choice such 'usual', 'not important' and 'very not important' got no respondent to choose at all. 15 boy students of the total 22 choose 'very important' while the rest choose 'important'. Meanwhile, 22 girl students of the total 25 choose 'very important' while the rest choose 'important' as shown in the diagram 1.1 and 1.2. 


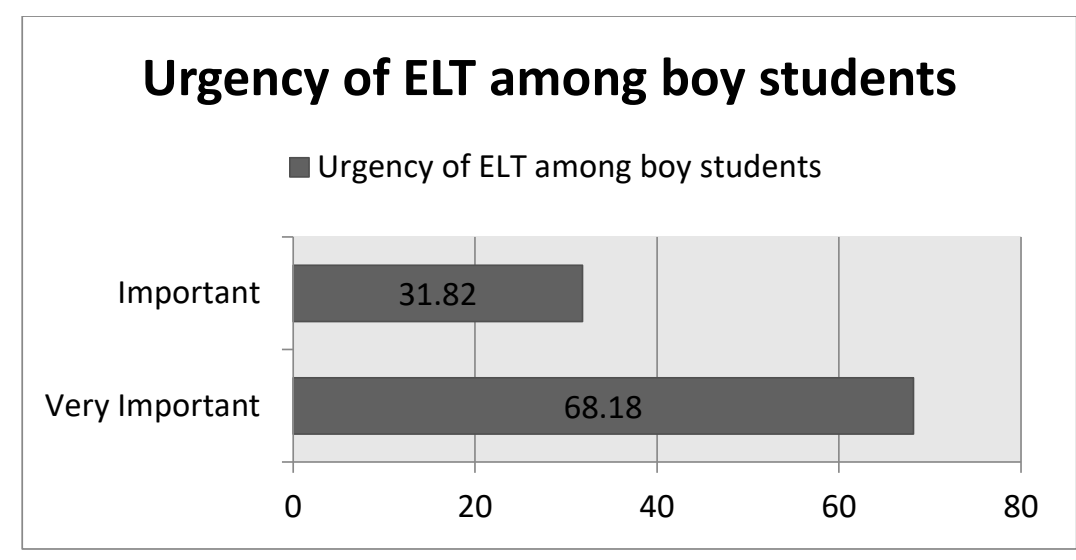

Diagram 1. Percentage of Boy Students toward Urgency of ELT in Pesantren

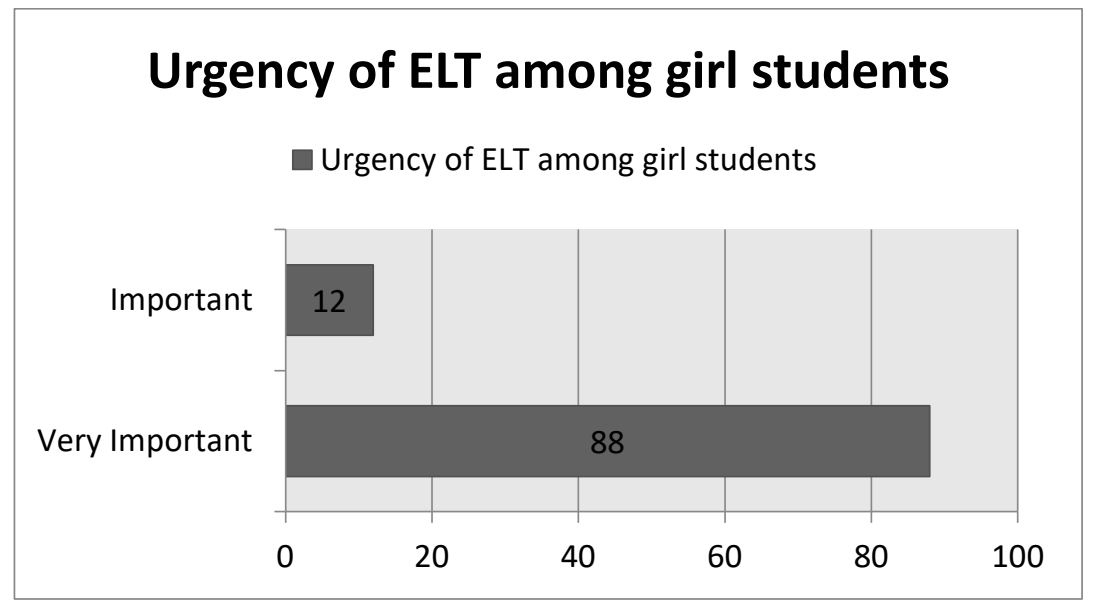

Diagram 2. Percentage of Girl Students toward Urgency of ELT in Pesantren

\section{- Learning Motivation among Students}

Type of learning motivation is included to be measured in this research since motivation got significant role to determine behavior and students perspective toward the ELT. In measuring motivation, researcher refers to classification of motivation which is made by Gardner (1985) and another version which been promoted by Decy and Ryan (1985). Gardner's version comprised motivation into Integrative and Instrumental motivation, while Decy and Ryan's version classified it into Intrinsic and Extrinsic. Each question in the questionnaire has adopted examples of these four types of motivation. 


\section{Learning Motivation among boy students}

Pursuing abroad Scholarship

Comfortably intend to learn...

Having ability to...

Increasing and Developing...

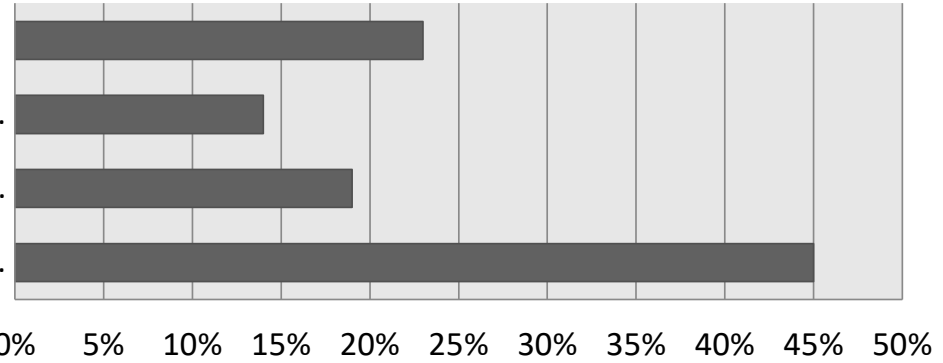

\begin{tabular}{|c|c|c|c|c|}
\multicolumn{1}{c|}{} & $\begin{array}{c}\text { Increasing and } \\
\text { Developing } \\
\text { General } \\
\text { Knowledge }\end{array}$ & $\begin{array}{c}\text { Having ability } \\
\text { to } \\
\text { communicate } \\
\text { with foreigner }\end{array}$ & $\begin{array}{c}\text { Comfortably } \\
\text { intend to learn } \\
\text { foreign } \\
\text { language }\end{array}$ & $\begin{array}{c}\text { Pursuing } \\
\text { abroad } \\
\text { Scholarship }\end{array}$ \\
\hline $\begin{array}{c}\text { Learning Motivation among } \\
\text { boy students }\end{array}$ & $45 \%$ & $19 \%$ & $14 \%$ & $23 \%$ \\
\hline
\end{tabular}

Diagram 3. Percentage of Learning Motivation among boy students

\section{Learning Motivation among girl students}

Pursuing abroad scholarship

Comfortably intend to learn..

Having ability to...

Increasing and developing..

Desire to Pass National...

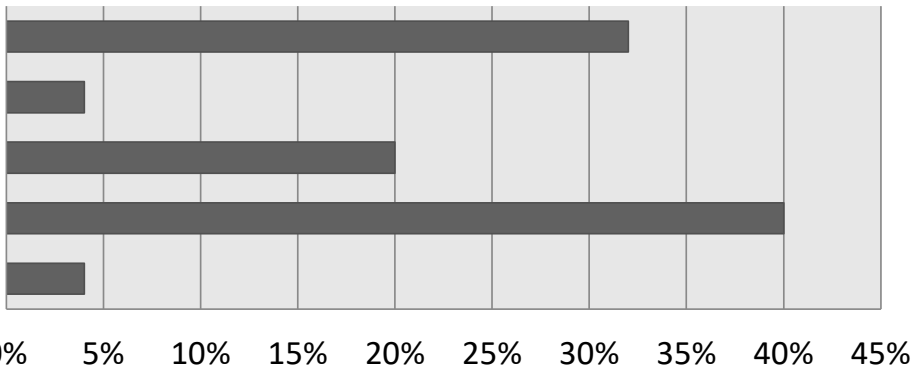

\begin{tabular}{|c|c|c|c|c|c|}
\cline { 2 - 6 } \multicolumn{1}{c|}{} & $\begin{array}{c}\text { Desire to } \\
\text { Pass } \\
\text { National } \\
\text { Examinatio } \\
\mathrm{n}\end{array}$ & $\begin{array}{c}\text { Increasing } \\
\text { and } \\
\text { developing } \\
\text { General } \\
\text { Knowledge }\end{array}$ & $\begin{array}{c}\text { Having } \\
\text { ability to } \\
\text { communica } \\
\text { te with } \\
\text { foreigner }\end{array}$ & $\begin{array}{c}\text { Comfortabl } \\
\text { y intend to } \\
\text { learn } \\
\text { foregin } \\
\text { language }\end{array}$ & $\begin{array}{c}\text { Pursuing } \\
\text { abroad } \\
\text { scholarship }\end{array}$ \\
\hline $\begin{array}{c}\text { Learning Motivation among } \\
\text { girl students }\end{array}$ & $4 \%$ & $40 \%$ & $20 \%$ & $4 \%$ & $32 \%$ \\
\hline
\end{tabular}

Axis Title

Diagram 4. Percentage of Learning Motivation among girl students 


\section{- Application of ELT in Pesantren}

In this variable, researcher explores students perspective toward the running ELT which they had in formal class through formal teaching under national curriculum. Through this side, researcher is exploring students feeling whether it is 'Very Exciting', 'Exciting', 'Usual', and 'Boring' or 'Very Boring'. Among these choices respondents are having various choices, specifically between boy and girl students. 6 boy students of the total 22 stated that ELT application was 'very exciting', 10 of them choose 'exciting', 5 of them choose 'usual' and 1 of them choose 'boring' option. Meanwhile, among 25 girl students 5 of them choose 'very exciting', 18 of them choose 'exciting' and the rest of them choose 'usual'. Hence, the percentage of the compiled numerical data

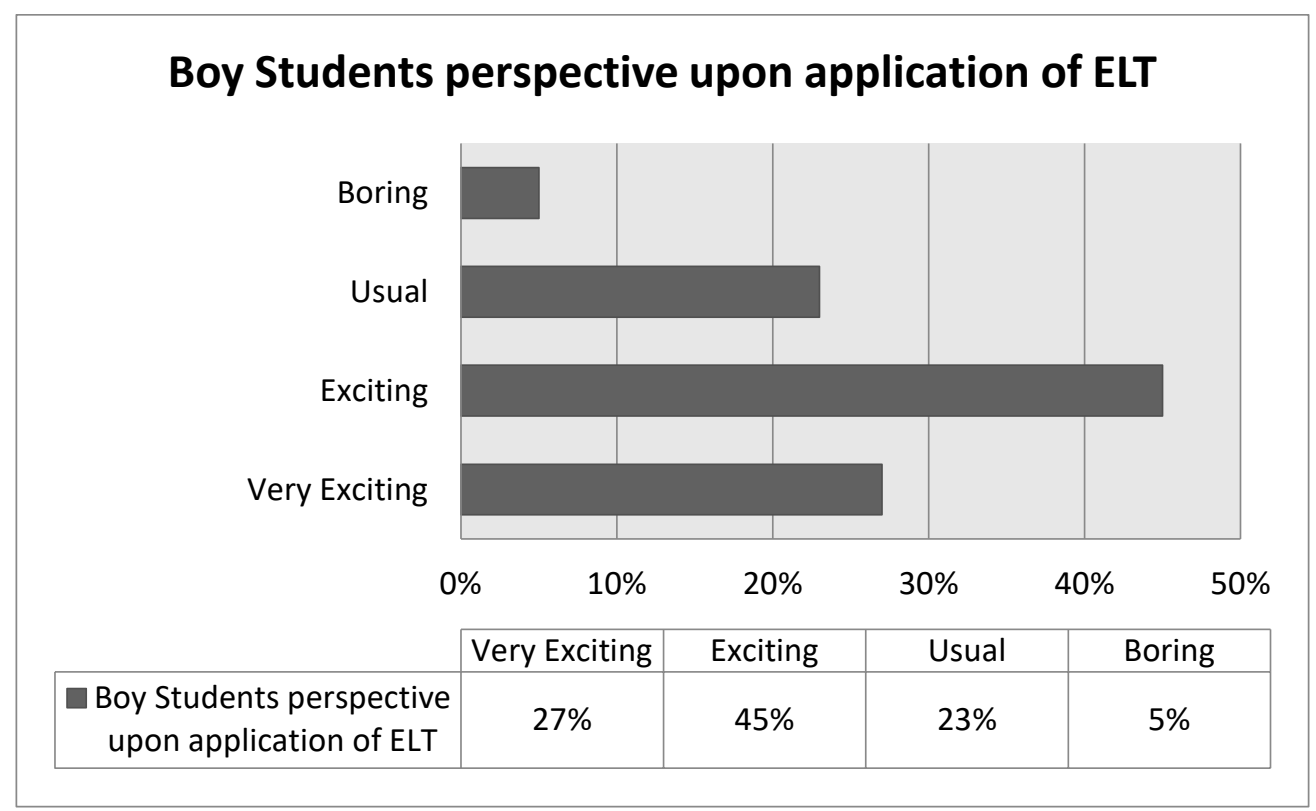

Diagram 5. Percentage of boy student perspective toward ELT application 


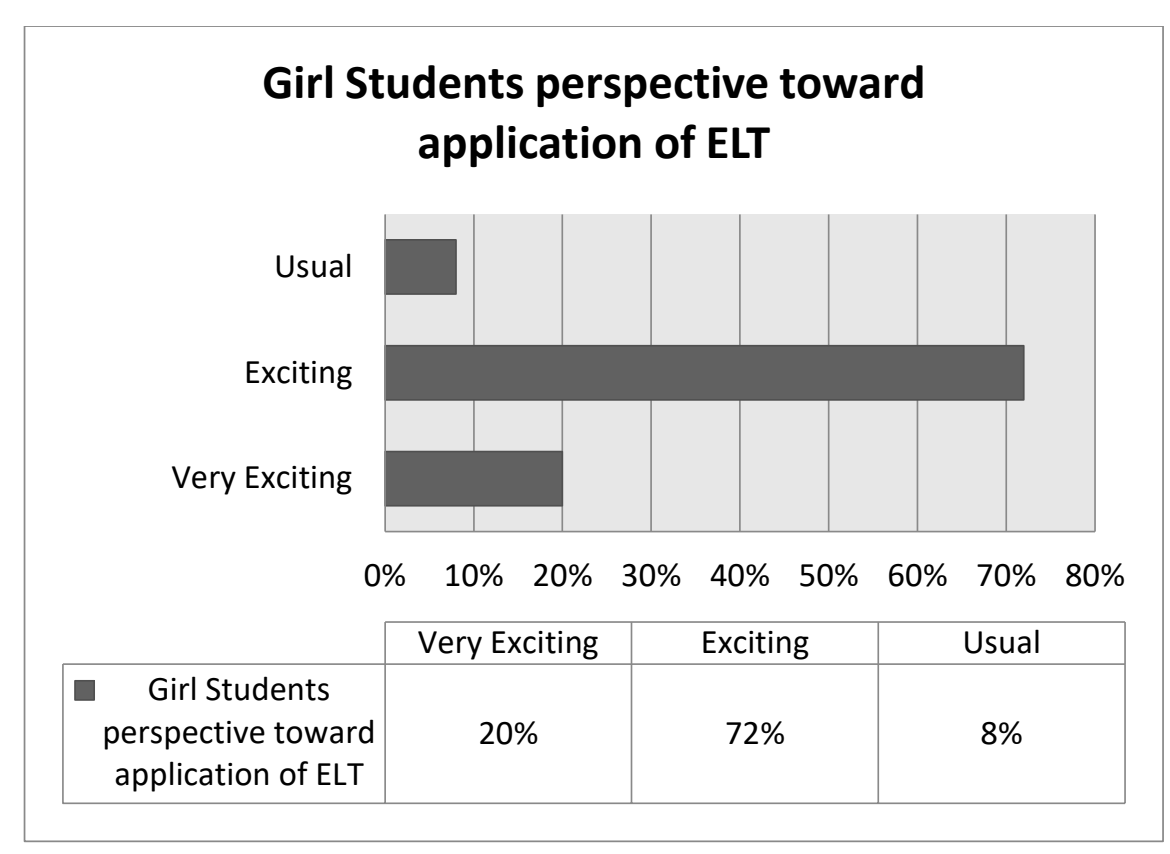

Diagram 6. Percentage of girl students perspective toward ELT application

\section{- ELT method in Pesantren}

In this variable researcher explored student perspective toward ELT method which they got along the academic year in the classroom. Hence are the following percentages of compiled numerical data from the questionnaire

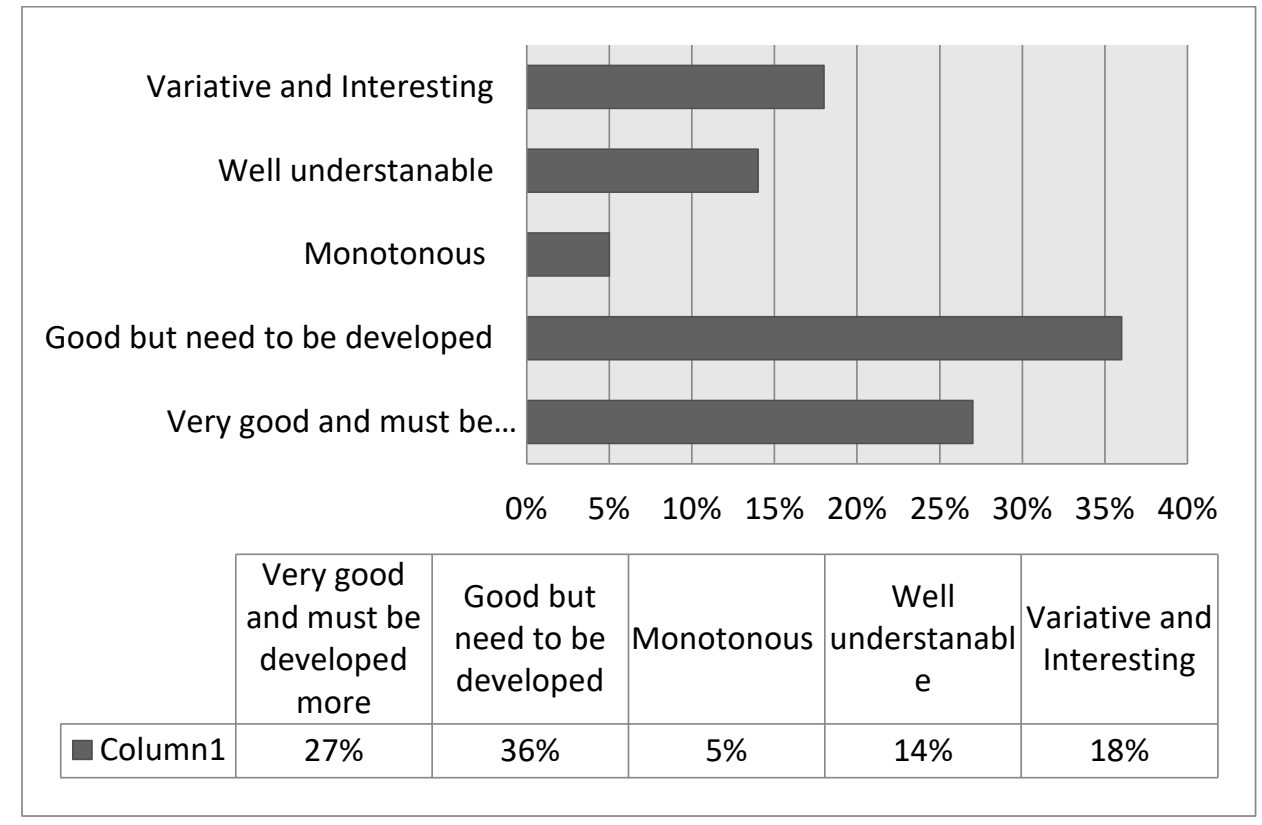

Diagram 7. Percentage of boy student perspective toward ELT method 


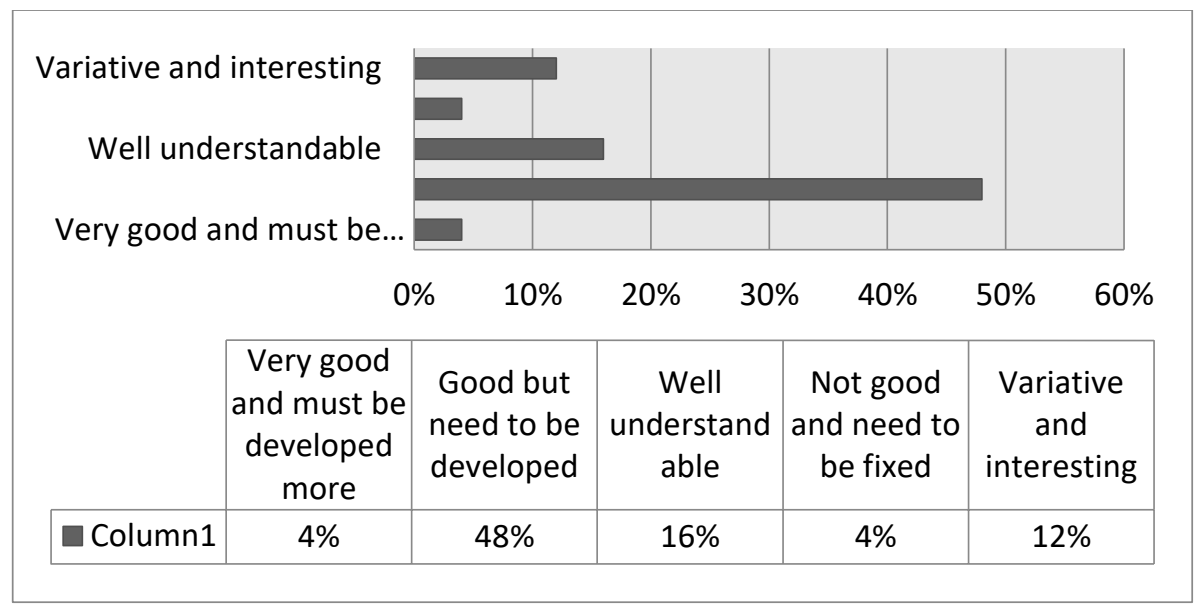

Diagram 8. Percentage of girl student perspective toward ELT method

\section{- Teaching and Learning Instrument of ELT in Pesantren}

In this section, question is designed to touch students perspective on teaching and learning instrument which been used in ELT along the academic year. Students are supposed to be remembering various instrument which been used so far and how complete it is based on their perception of an ideal teaching and learning.

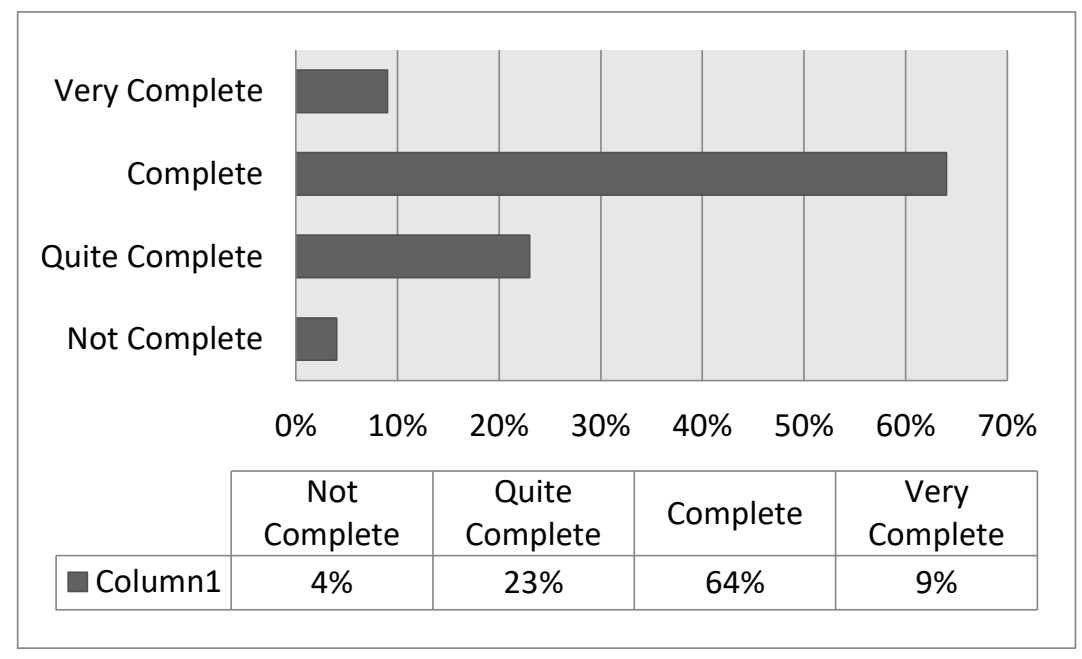

Diagram 9. Percentage of boy student perspective toward teaching and learning instrument of ELT in Pesantren 


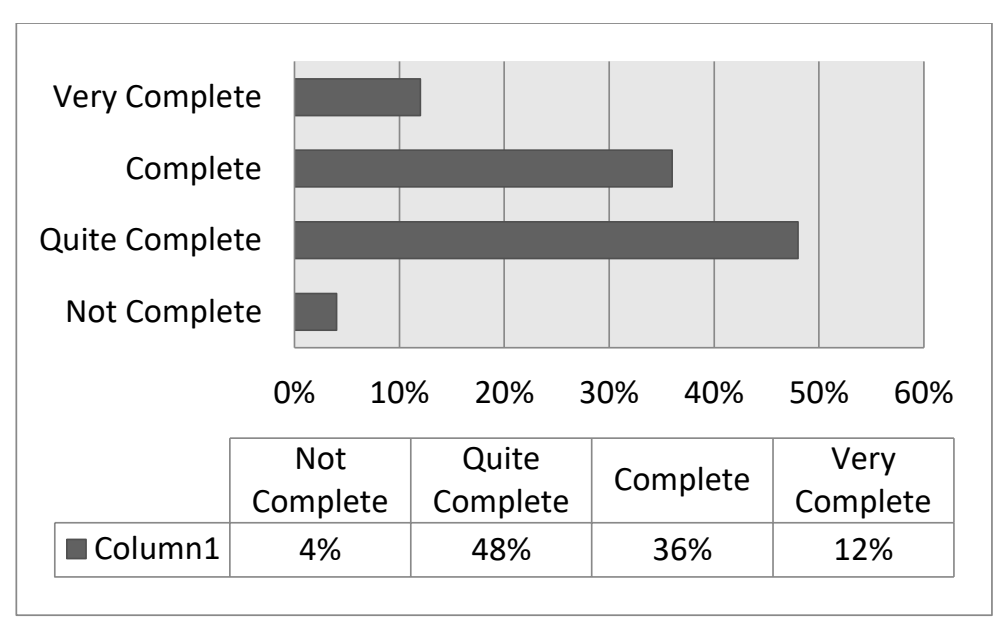

Diagram 10. Percentage of girl student perspective toward teaching and learning instrument of ELT in Pesantren

\section{- Significance of Supporting Environment toward ELT in Pesantren}

As mentioned in the introduction of this research, that Pesantren is a unique community which has its own internal regulation, specifically to force the students to use official language (Arabic or English). This regulation formed in the integrated environment between school and dormitory, so it is essential to know students perspective toward this kind of environment associated to the ELT.

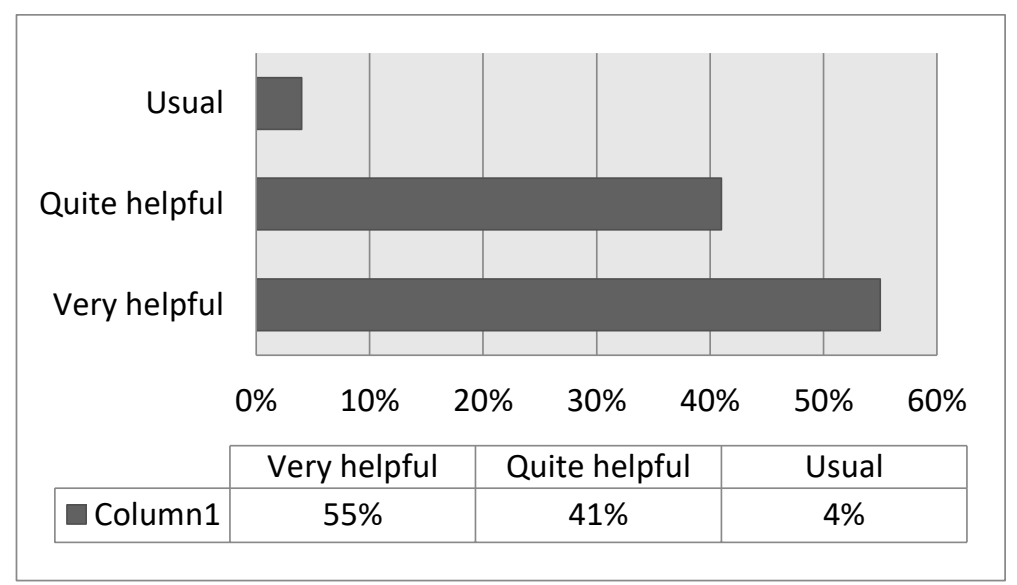

Diagram 11. Percentage of boy student perspective toward supporting environment for ELT in Pesantren 


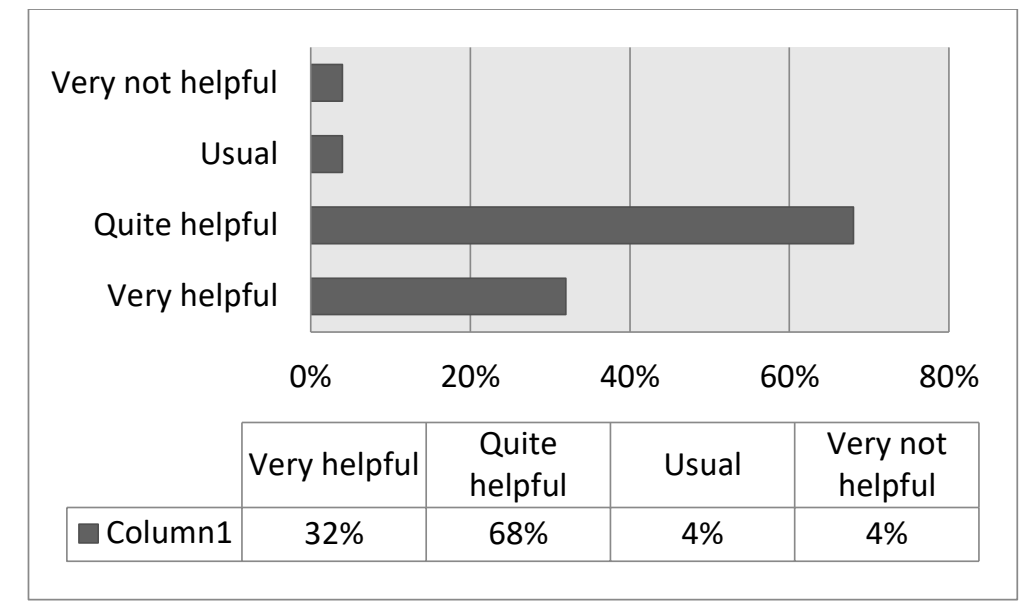

Diagram 12. Percentage of boy student perspective toward supporting environment for ELT in Pesantren

The following parts are the result of interview. The respondents involved two teachers and Head of Language Enforcement Department in the institution.

\section{- $\quad$ Interview Result with English Teacher A}

\section{- Urgency of ELT}

English is a tool (instrument) which is used to learn the knowledge. Therefore, it is very important since we really hope that after graduation from this institution, our students are competent to compete, specifically with non-pesantren student. Moreover, our institution is a modern pesantren that put high attention to the usage of bilingual (arabic and english) in daily activities.

\section{- Learning Motivation}

Our students have extra-ordinary motivation eventhough they are learning inside pesantren. Some of them have planned to continue their study abroad. And so far, we have alumi who are continuing their study in Sudan, Egypt and Yemen. Those who are continuing their study in Indonesia had also succeed to enter favourite University such ITB, UNAIR and UGM and some others.

\section{- Application of ELT}

Pesantren students are different with other student. In pesantren, we educate them to honor teacher, this honor must be placed before everything. That is why, they always be obidient to the teacher and so far I got them so much obidient and having positive behaviour to almost every single subject which been taught in the classroom.

\section{- ELT Method}

In our institution, ELT is chategorized into 2, and I got my responsibility to handle what we called as 'Drilling English Program' which put big attention in enhancing grammar (structure) as they are prepared to pass TOEFL at grade XII. Meanwhile, for grade X and XI we also teach them structure and practices. The other program will be regular english which run in accordance with national curricullum from the Education Ministry of Indonesia.

\section{- Instrument of ELT}

Regarding to the teaching instrument, honestly our instrument is still lack (not complete), because in ELT we supposed to have minimally one language laboratory and till now we don't have it yet. But we are working to provide it in the next years. 
- Significance of Environment

Language regulation must become such habit for students. We obligate our students to use both arabic or english in daily live. There are some days when they are allowed to use javanese, but at most they must use arabic and english as medium of communication. And in case that they are caught using non-arabic or english, they will be punished according to our internal regulation. Therefore, they will feel responsible to use official language in our environement.

\section{- $\quad$ Interview Result with English Teacher B}

\section{- Urgency of ELT}

Once our students can use English, perhaps they will be able to master the knowledge itself. So, prospectively they will not get any obstacle when they study abroad. Huge number of our alumni had continued their study abroad. Moreover, some of Indonesian Universities have their international class which deploy English as medium of instruction.

\section{- Learning Motivation}

Indeed, they have good motivation, specifically when they are in XII grade, since they are about to continue to the higher education. For instance, when they are pursuing study in tourism and hospitality, some of them have approached me and say that they are so much regretful for not mastering English since grade XI and XII. So they will occupy most of their attention to learn TOEFL in order to meet the requirements for tourism major.

\section{- $\quad$ Application of ELT}

Each class has its own character and behavior. It is not about science or social track, but it most goes to the class composition which determined the whole class behavior. Commonly, they are enthusiastic, only some of them are not. But in percentage, most of them behave positively.

\section{- ELT Method}

We used many methods, for instance communicative language teaching and many more. Sometimes, we also use discussion format, perhaps depending on the subject and material. Once I ever taught about narrative, and I start the class with drama and they are very enthusiastic, since each of them got distinctive role and chance. Even though their language is still in average level as I always give them corrections.

\section{- Instrument of ELT}

We don't have language laboratory yet. But for other instrument such portable sound system for listening, we have it. I also sometimes brought my own portable sound system.

\section{- Significance of Environment}

Honestly, our students' competency in language tend to go more in Arabic rather than English. So, they are a bit lack in English. Indeed, they have competency in English, but they are still lack for the daily application. 
- $\quad$ Interview Result with Head of Language Enforcement Department

- Language Program

First of all, we have daily program including vocabulary enhancement. It is held after Shubuh prayer when students' minds are still fresh, so we enrich them with vocabulary. In a day 3 vocabularies are given to them in three languages (English, Arabic and Bahasa Indonesia), the program run for twenty to thirty minutes. We have also weekly program such listening and watching movie at the Sunday except for those who are visited by their parents. Specifically for grade VII SMP and X MA they must attend intensive class on Friday to deepen their language.

\section{- Environment Conditioning}

Yes, we are the one who give them punishment and warning for those who don't use our official language. But, if they keep repeating same mistake, we will report them to the board of teachers. During our daily operation, we cooperate with dormitory officials. Our member of language department also often walk through inside the buildings to patrol language application.

\section{- Purpose of Learning English}

Maybe, later on, when students have graduated, there will be many majors to choose and moreover, universities are demanding TOEFL (for English) and TOAFL (for Arabic) as entry requirement. In addition, having ability to speak English will help them to get scholarship from International Universities, ability to communicate with foreigner is also beneficial since there are many tourists in Indonesia.

\section{- Students Behavior}

Commonly, many students are following our program positively, though some of them are quite difficult to be managed. For them, we need to provide such special treatment such private advising.

\section{- Focused Skill in ELT}

In Pesantren we are trying to enrich vocabularies and direct practice. Vocabularies are taught in each group and students are also being tested after memorizing the vocab.

\section{DISCUSSION}

First variable which been measured is about stakeholders' perspective toward urgency of ELT, and in accordance to the data we can see some pattern of congruency and conformity among the stakeholders. Both male and female students are displaying positive tendency to consider ELT as very important in Pesantren. However, female students are having higher percentage of importance consideration as $88 \%$ of them are stating ELT as 'very important' compare to male which only reach $68.18 \%$. Despite, this positive trend has also met others' (teachers and head of language department) perspective who stated the urgency of ELT. The highlighted point in this part is that perspective congruency in the matter of urgency of ELT has found and so far became significant capital for the prospective ELT development. 
In teachers perspective, English has considered as a tool or instrument which been used to master and acquire knowledge or to pursue another goal. This perspective has also performed congruency with the students'; as both male $(45 \%)$ and female $(40 \%)$ are dominantly stated their learning motivation in ELT is 'increasing and developing general knowledge'. This fact doesn't stop here, as the second highest of their learning motivation is 'pursuing abroad scholarship'; male (23\%) and female (32\%). Based on this percentage, researcher can conclude that female students are more motivated to pursue international education compare to male students. $20 \%$ female and $19 \%$ male students have displayed that their learning motivation in ELT is to have enough ability to communicate with foreigner. The rest $14 \%$ of male students have displayed that they barely intend to learn English because they feel comfortable and happy to learn foreign language, meanwhile female students have only $4 \%$ on this type of motivation. The rest minor type of motivation is 'desire to pass national examination' which only shown by $4 \%$ of female students. In accordance with this data, researcher can conclude that Pesantren students are instrumentally motivated to learn English, as Hudson (2002) stated that instrumental motivation is indicated by aspiration to get practical benefit from the study of language.

On the third variable, application of ELT, both male and female students have commonly displayed positive attitude toward the application of ELT as $45 \%$ of male student stated that it is 'exciting', while $27 \%$ of them stated 'very interesting'. Female students have also high percentage on the excitement since even $72 \%$ of them have displayed it. In addition, $20 \%$ of them have stated that ELT application is 'very exciting'. Despite this positive trend, a quite percentage of negative behavior is exist, specifically among male students as $23 \%$ of them stated that ELT application is 'usual'. This percentage is quite high compare to female students which only performed minority number $8 \%$. A discrepancy has been found in associated to the statement of one teacher who said that almost all students have positive perception toward all subject and all teacher, because in fact, they are varied as stated congruently by another stakeholders.

The topic of ELT application has actually a very close tie with the used method of ELT, as the used method will determine students' response toward the ELT since it delas with techniques implemented to activate their language knowledge. In the issue of ELT method, students perspectives also vary. Among male students, $36 \%$ stated that the method is 'good but need to be developed', 27\% stated 'very good and must be developed'. 18\% of them stated 'varied and interesting', 14\% of them stated that it was 'well understandable' and 
the rest of 5\% stated that it was 'monotonous'. Meanwhile, female students have also as much as male type of perspective; $48 \%$ of female students stated that the method is 'good but need to be developed', 16\% stated 'well understandable', 12\% stated 'varied and interesting', $4 \%$ stated 'very good and must be developed, while the rest $4 \%$ stated that the method is not good and need to be fixed. Both male and female have majority considered that the method is good so far, but they also found several sides which need to be developed more. In addition, there are always tiny percentage of both male and female students who feel that the method is either usual, monotonous or even need to be fixed. As the exact reason of background of each case may vary, further research should be conducted in order to reveal this tiny percentage of negative perspective, whether it is because of the lack of method or even students' critical analysis and probability of misleading expectation. The thing that can be proposed to make the learning situation more interesting in through games and interesting method. The researchers showing the impact of games in language learning are from Arbain \& Nur (2018) who talk about the power of magic and fairy tale dice and (Kusuma, Adnyani, \& Taharyanti, 2017) who develop 10 interesting English games. Another one is Afidah \& Ma'arif (2017) who discuss their magic finger method in Grammar lesson.

The next two measured variable are instrument of ELT and significance of environment in Pesantren, which both are associated one to another. Perspective toward instrument of ELT is the unique part of this research, as it also revealed another discrepancy. Students are mostly considering that ELT instrument in Pesantren has been completed, or even very complete. $64 \%$ of male students stated that ELT instrument in Pesantren is 'complete' and $23 \%$ of them stated 'quite complete'. Another $9 \%$ of them even stated 'very complete', and the rest 4\% stated 'not complete'. Meanwhile, unique pattern has emerged among female students as only $36 \%$ of them stated that the instrument is 'complete', while ' $48 \%$ of them stated 'quite complete'. $12 \%$ of them stated 'very complete' and the rest $4 \%$ stated 'not complete'. Regarding to male students, the range of congruency with teachers' perspective is very large. During the interview, teachers admit lack of instrument such the absence of language laboratory as the minimum instrument in ELT. The presence of another instrument such portable sound system still don't drive it better since teacher sometimes must bring their own portable sound system. Female students displayed more critical point of view since majority of them (48\%) stated 'quite complete' and 36\% stated 'complete'. Another $12 \%$ stated 'very complete' and the rest $4 \%$ stated 'not complete'. Despite the positive trend 
is still dominant, but the percentage of $48 \%$ which is still higher rather than another perspective.

Lastly, the measurement toward significance of environment has displayed congruency between students (male-female) and another stakeholder. Despite lack of instrument, Pesantren has its internal language regulation which also can be considered as supportive instrument to reinforce language development in Pesantren. The significance of this environment has been positively recognized by all stakeholders. Among male students, $55 \%$ of them stated it is 'very helpful', $41 \%$ stated quite helpful and the rest of $4 \%$ stated 'usual. Among female students, $60 \%$ of them stated 'quite helpful', while $32 \%$ of them stated 'very helpful', 4\% stated 'usual' and the remaining 4\% stated 'very not helpful'. It is a bit strange to find option 'very not helpful' among female students which often have a positive trend of perspective. Researcher estimates that this rare phenomenon is pop up due to personal problem, such entering Pesantren by force or lack of competence in following language law enforcement in Pesantren.

\section{CONCLUSION}

In accordance with the finding and discussion above, researcher finally constructs the final conclusion of this research in several points.

Firstly, all stakeholders of ELT in Pesantren Al Amanah have agreed and congruently consider English as very important subject to learn, but they may have different causes to determine its urgency. Teachers and head of language department consider English as tool and instrument to master knowledge, but students' perspective may differ as some of them are pursuing international scholarship. The perspective congruency toward urgency of ELT is the first capital to seize a conducive milieu of ELT.

Secondly, it is clear that most of the students at Pesantren Al Amanah have been more instrumentally motivated during ELT. So, course design conformity with students expectation and motivation is firmly suggested to achieve better satisfaction among all stakeholders.

Thirdly, in the topic of ELT application, a small scale discrepancy has occurred. It is true to say that majority of students have positive behavior toward ELT application, but generalization must be avoided to maintain the development of ELT application itself. Students' behaviors are varied in each class as confirmed by one of the teacher.

Fourthly, regarding to the instrument of ELT, students are mostly have good perspective, unless it does not congruent with the fact and teachers perspective. The range of 
discrepancy is quite remarkable among male students, though female students have differed their perspective and closer to the congruency with other stakeholder. This discrepancy may be caused by the lack of ideal learning instrument in ELT. A harmonization led by teachers by explaining the real condition and the ideal one is needed in order to solve the problem by involving all stakeholders, including students.

Finally, measurement on the significance of environment has driven into conclusion that most of the students are feeling significantly helped by the set up environment and its regulation. Despite, there are still minor perspectives to be concerned by the stakeholders, such personal uncomfortability toward the regulation. Further modification and harmonization are very suggested by doing comparative study to another Pesantren, having a similar platform of language application and future prospect.

\section{BIBLIOGRAPHY}

Afidah, N., \& Ma'arif, I. B. (2017). Utilizing Magic Finger Method in Grammar Class. JEES (Journal of English Educators Society), 2(1), 45. Retrieved from https://doi.org/10.21070/jees.v2i1.677

Arbain, A., \& Nur, D. R. (2018). The Use of Magic and Fairy Tale Dice to Improve Students' Ability in Writing Narrative Text. Retrieved from https://www.atlantispress.com/proceedings/icigr-17/25890845

Deci, L. ., \& Ryan, M. R. (1985). Intrinsic Motivation and Self-Determination in Human Behavior. New York: Plenum.

Entwistle, N., \& Tait, H. (1990). Approaches to learning, evaluations of teaching, and preferences for contrasting academic environments. Higher Education, 19, 169-194.

Fahruddin, D. (2015). English Language Teaching in Pesantren Institution in Indonesia; From Colonial to Global Perspectives. In Prosiding for 4th International Conference on Indonesia Studies; "Unity, Diversity and Future."

Gardner, R. C. (1985). Social psychology and second language learning: the role of attitudes and motivation. Baltimore, Maryland: Edward Arnold.

Hidayat, M. (2007). The Teaching of English at Pondok Pesantren At Tarbiyyah Al Islamiyyah in Paiton, Probolinggo. The State Islamic University of Malang.

Hudson, G. (2000). Essential introductory linguistics. Blackwell Publishers.

Könings, K. D., Brand-Gruwel, S., \& van Merriënboer, J. J. G. (n.d.). Students' and teachers 'perceptions of an innovative learning environment: Do they see through the same glasses?

Kothari, C. R. (2004). Research Methodology; Methods and Techniques (Second Revised Edition). India: New Age International Publishers.

Kusuma, I. P. I., Adnyani, N. L. D. S., \& Taharyanti, G. A. P. (2017). Developing 10 Interesting Games as the Breakthrough of Monotonous Implementation of Flashcards to Vocabulary Learning and Assessments. Script Journal: Journal of Linguistic and English Teaching, 2(1), 68. https://doi.org/10.24903/sj.v2i1.65

Mukhlas, M., \& Fadhilah, E. (2016). The Influence of DCM (Daily Conversation Method) towards Students Foreign Language Speaking Fluency in Modern Islamic Boarding School in Indonesia. In Proceeding of SOCIOINT 2016, 3rd International Conference 
on Education, Social Sciences and Humanities (p. 23-25 May). Istanbul, Turkey. Risdianto, F. (2016). Model Pembelajaran Bahasa Inggris di Ponpes Ta'mirul Islam Surakarta. LEKSEMA; Jurnal Bahasa Dan Sastra, 1(No. 1, Januari-Juni 2016). Vermetten, Y. J., Vermunt, J. D., \& Lodewijks, H. G. (2002). Powerful learning environments? How University students differ in their response to instructional measures. Learning and Instruction, 12, 263-284. 